\title{
Kinship Studies in Brazil ${ }^{*}$
}

\author{
Roque de Barros Laraia
}

“They respect their brothers' daughters because they consider them as daughters and treat them as such; they do not fornicate with them, as for them real kinship comes through the father, who is the agent. The mothers, compared to the fathers, are nothing more than containers in whom the child is bred, and for this reason the fathers' children, even when mothered by slaves or captive enemies, are always free and as respected as the others. But the children of the females that are the children of captive enemies are kept as slaves or sold; sometimes they kill them and eat them, even if they are their grandchildren, their daughters' offspring. For the same reason they unashamedly use their daughters' daughters for copulation, without any obligation or general custom to take them as wives, as is the case with the others, as it is said ..."

José de Anchieta

"Information on marriage among the Indians of Brazil"

Modern Brazilian anthropologists are, obviously, aware than kinship is one of the most important aspects of social organisation, notably in so-called simple societies where it is one of the basic principles on which all social life depends. Consequently the quest for understanding kinship is one of the main concerns of Brazilian anthropology.

The truth, however, is that our concern with the study of kinship only acquired importance in the second half of this century. Until then it had remained relegated to an inferior position, due possibly to a lack of adequate theoretical training that would permit analysis of this important social phenomenon.

In this essay I intend to demonstrate that it is possible to establish a periodicity that divides the history of Brazilian anthropology, as far as kinship is concerned, into two periods: the first, that lasted until the middle of

\footnotetext{
* Originally written for an anthology of Brazilian anthropology for publication in the United Sates, organised by Daniel Gros and Gustavo Sérgio Lins Ribeiro.
} 
the $20^{\text {th }}$ century, was characterised by a low level of interest in the study of kinship, and a predominance of self-taught researchers. This was the heroic period of our science, marked by the presence of a great custodian, Curt Hunkel, who was later to become Curt Nimuendaju, the father of Brazilian ethnology'; and a second period, marked by an interest in kinship studies, undertaken, in the vast majority of cases, by researchers who had received adequate academic training.

In the first period, Curt Nimuendaju set about compensating the deficiencies of his training by acquiring guidance from a leading name in American anthropology, Robert Lowie. We can imagine the difficulties this orientation entailed, always from a distance, without the two ever having met, aggravated by the Second World War and the prohibition of communication in German, the only language the two men shared. Even so, it must be recognised that Nimuendaju was the first Brazilian anthropologist to be concerned with the subject of kinship and his work became the basis for a productive discussion between modern anthropologists in the 1960's.

Examining the four monographs - The Apinayé; The Serente; The Eastern Timbira and The Tukuna, at least one of them reveals his concern to relate the terms of kinship and the existence of unlinear descent groups. It is true that in two cases - The Apinaye and The Tukuna - the kinship terminology was only published in the appendices. It is also evident that no preoccupation at all exists with the analysis of kinship systems, the relevant chapter rather describing the life cycles, amongst which matrimony is included, with no effort being made to establish its most prevalent forms. Only in the case of the Xerente did Nimuendaju dedicate a little over a page to analysing the behaviour between kinsfolk, above all between siblings.

In the 1940's, when Curt Nimendjau's monographs were published - the fruit of fieldwork during the previous decade - there was little else available on kinship. It was the period when Rodolfo Garcia (1942) and Carlos Drummond (1943) published their work on the "kinship designations in the Tupi-Guarani language." These are, however, linguistic works that restrict themselves to listing terms of kinship taken from the writings of $16^{\text {th }}$ century chroniclers. There is no anthropological analysis of the terms collected. Also in the 1940's Virginia Watson (1944) published a list of Cayuá kinship terms, collected during research carried out with her husband, James Watson.

In 1946, Charles Wagley and Eduardo Galvão undertook a broader study of 
the topic examined by Garcia and Drummond, which they published in their article "Tupi Guarani Kinship" that consisted of an analysis of data from $16^{\text {th }}$ century chroniclers combined with contemporary research. This article, as I will later show, is the first of a series of analyses on Tupi social structure. ${ }^{2}$ In 1948 these same authors published a chapter in the Handbook of South American Indians, in which they analyse, albeit superficially, the social organisation of the Tapirapé and the Tenetehara. The following year Wagley and Galvão published The Tenetehara Indians of Brazil: A Culture in Transition (1949), which is without doubt the first monograph that seeks an understanding of a Tupi society based on knowledge obtained from fieldwork. The same year, Florestan Fernandes published his book A Organização Social dos Tupinambá, which is in turn the first attempt in our specialised literature to reconstruct an extinct social reality, based on the documentation left by $16^{\text {th }}$ century chroniclers 3 . I will analyse all these works according to the extent to which they relate to Tupi kinship.

The following decade began with the publication of James Watson's Cayuá Culture Change: A Study in Acculturation and Methodology, in 1952, originating from research conducted by the author in 1943. Watson wrote on the social organisation of this Guarani group in Mato Grosso. Despite the difficulties of obtaining information on the group's past, he attempted to show the similarity of the matrimonial rules with those of the coastal Tupi. The same year Baldus published an article on Kaingang kinship, and, two years later Egon Schaden published his monograph Aspectos Fundamentais da Cultura Guarani.

The 1950's saw the entry of Darcy Ribeiro into Brazilian anthropology; it was during this period that he published his article on the kinship system of the Kadiweu, the only time he was to broach this subject. He did not, for example, publish his data on the social organisation of the Urubu-Kaapor, despite the excellent work he published on their feather-work art and the organisation of their economic activity.

An important work of this period was Roberto Cardoso de Oliveira's "Matrimônio e Solidariedade Tribal Terena" (1959), which goes far beyond a mere description of the kinship terminology of the Terena, constituting a structural analysis of their social organisation, that presents a particular characteristic: the existence of a dual endogamic system. Cardoso de Oliveira shows how this apparently dysfunctional aspect is counterbalanced by exogamy in the villages, making social cohesion possible. 
The second period begins in the 1960's. I will now proceed to examine the development of kinship studies in Brazil without concern for chronological or even hierarchical order.

The 1960's were characterised by the influence of a certain type of American anthropology which can be divided into two schools, one of which was based, somewhat belatedly, on George P. Murdock's work Social Structure, that to some extent was the forerunner of the cross-cultural method, and the other, more contemporary, taking its inspiration from the writings of Ward Goodenough that advocated the use of componential analysis. Both schools made a great impression on Brazilian researchers, precisely at the time that they were concerned with giving greater emphasis to the study of kinship. Few publications resulted from the influence of these two schools, even though a large number of researchers and students engaged in numerous exercises. At that time the impression existed that anthropology had at last achieved a truly scientific status. Brazilian anthropologists easily adopted the approach advocated by Murdock, since a tradition had already been established during the previous decade of publishing articles that consisted of no more than a list of kinship terminologies, often without the slightest attempt to relate them to the rules of matrimony or residence. Murdock's method gave the impression that one could go further; that it was possible to develop a classification, taking into consideration the terms for uncles, cousins and the rules of residence and descent. The fragility of this approach, that soon became evident, resulted from the impossibility to infer the dynamic of the social structure based on such a limited number of variables. The variables had a high rate of recurrence in very different societies. The aim of this method was to understand some of the characteristics of the societies that were studied, based on their classification as one of the eleven types of social organisation produced by Murdock, a typology that was immediately contested by Needham when he showed that kinship terminologies virtually identical in form are not always structurally equivalent (1962:174). In effect these considerations reflect the concern with a genealogical perspective rather than the production of an integrated set of categories, from which it would be possible to outline the "social universe" of the group studied.

The works cited by Baldus, Ribeiro and Virginia Watson are examples of the beginning of this phase, while those of Arnaud and Frederick MacDonald are characteristic examples of works produced at the end of this phase. 
At the outset kinship studies in Brazil did not give any great importance to an element that is crucial to the understanding of the phenomenon of the ideology of biological conception constructed by the group in question. Kinships systems are associated with the type of explanation of human reproduction that is constructed by distinct societies. These explanations were formulated even before humanity had adequate resources for scientific observation, but earned the status of 'scientific truths'. That is why Lévi-Strauss (1958:61) stated that "a kinship system does not consist in the objective ties of descent or consanguinity between individuals. It exists only in human consciousness; it is an arbitrary system of representations, not the spontaneous development of a real situation." In other words biological relationships only serve as a point of departure for the development of the sociological conceptions of kinship.

It was only from the 1960's onwards that this important aspect of social classification began to receive the attention of the anthropologists who study Brazilian Indians. The previous years offer just one exception, and this, as is to be expected, is to by found in Curt Nimuendaju's monograph on the Tukuna: "after intercourse, conception depends on the will of the goddess Ta'e: it is she who gives the foetus its body and soul. When, overburdened with tasks, Ta'e grows careless, the child is born with defects in mind or body" (1952:68). The other works of the period prefer to seek their explanations through the analysis of terminology; a viable but torturous route, which runs the risk of resulting simply in controversial typological constructions.

From 1966 onwards the concern with the conception of conception became frequent. Terence Turner, for example, affirms that: "the Cayapo believe that conception takes place as a result of the semen travelling inside the mother's body into the mother's breasts, mixing with the milk which is inside the breasts even before the birth of the first child, and the resulting mixture dripping back down into the women. Conception is not a unique event: during the month before pregnancy is thought to begin, the child may be contributed to by the infusions of semen and milk, whether the semen comes from a single father or more than one man. During the gestation process, the foetus derives its nourishment from milk which continues to drip down to the womb from the breasts. Pregnancy is thought of as lasting only three to four months, the period during which the woman can detect a physical deformation and the movements of the foetus." 
The following year ${ }^{4}$ David Maybury-Lewis wrote about the Xavante: "Clearly then they understand the relationship between coitus and conception. However, they appear to view the fashioning of the child as a process induced by repeated copulation. Men have on two occasions expressed it for me this way: "tsihúri, tsihúri, tsihúri, tshúri; ahe-di wasã. Tsihúri, tsihúri, tsihúri; waptãr (to copulate, to copulate, to copulate, to copulate; pregnancy. To copulate, to copulate, to copulate; born). They ticked the process off of on their fingers so that "pregnant" fell on the fifth finger and "born" fell on the ninth. Other Savante spoke of the father making his child by repeated intercourses with his mother."

These two observations about the ideology of two Jê groups were confirmed by similar reports in works by Julio Cezar Melatti (1968) on the Kraho, by Roberto Da Matta (1970) and by Anthony Seeger (1974) on the Suya. Works undertaken outside the Jê area also concern themselves with the subject, as it the case with Peter Rivière writing of the Tirio of Pará: "There is a common soul form from which reservoir the individual draws his own soul. (...) An erection is caused by the spirit of the child in the penis and during the sexual intercourse both the spirit and flesh of the child flow into the woman, the sex of the child being decided in the penis. The patrilinear ideology does not receive unanimous support and, while no informant denied it outright, some said that the child's spirit came from both the father and mother, and others that the issue is even more strongly sex-linked, a male child possessing only the spirit of the father and the female child only that of mother. There is no preponderance of opinion on this subject, about which most Indians are ignorant or uninterested" (1969:62).

Alcida Ramos writing on the Sanuma refers to a very similar concept to that which I found among the Surui and Asurini (1967): "Although our data on the Sanuma theory of conception is limited, there are strong indications that they attribute most of the responsibility for conception to the father. Before the child is born, or rather before it is conceived, it is in the father's genitalia. Conception is associated with sexual intercourse, but not necessarily with menstruation" (1972:90).

Finally, Basso informs us that "the Kalapalo believe that conception occurs when repeated intercourse on the part of a single man results in the accumulation of congealed seminal fluid inside a particular woman. A woman who has promiscuous intercourse with many men cannot become pregnant; 
rather, she is in danger of falling seriously ill. Similarly, a woman who only has sporadic intercourse with a single man cannot conceive, because she has not received enough seminal fluid." (1973:75).

Writers previous to this period, above all those that worked with Tupi societies, did not take local understandings of conception into account, and consequently had great difficulty working with the system of kinship. The main consequence was a limited understanding of the rules of descent. Wagley and Galvão (1946), referring to the Kaiwa, Tenetehara and Tapirapé opt for the bilateral rule because "there is no emphasis in the system either for the maternal side or for the paternal one." James Watson (1952) takes a similar stance in relation to the Kaiwa, albeit recognizing the existence of the patrilinear rule amongst the Kaiwa in the past. Galvão (1953), referring to the Xingu tribes, states: "this system, as far as can be inferred through the comparison of the various terminologies collected, is of the bilateral type, that is, there is no emphasis either on the maternal or the paternal line." All these anthropologists are generally in agreement about the definition of the bilateral rule of descent, agreeing on the absence of any emphasis on either the paternal or the maternal sides. What is not acceptable in this definition, characterised by its negative determination, it that it can only be understood by the surprising observation that the authors consider that the existence of terms for both the paternal and the maternal side signifies bilaterality. In addition, it is also highly significant that none of them was concerned with the native idea of biological conception with the result that they were led to classify as relatives all those who received terms in the relations system. Not knowing the emic theory about conception, they failed to understand the distinction that exists between relatives and non-relatives. The mere translation of the kinship terms - ignoring the classic warning of Hocart (1937) - leads them to believing that those not recognised as relatives by the Indians are indeed relatives, and from this they draw the conclusion of the alleged bilateral rule of descent .

This mistake could have been avoided if more attention had been given to the legal aspects of descent. These aspects can be easily observed, for example, when there is a hereditary chiefdom, affiliation to a group of unilinear descent groups (lineages, clans etc.), transmission of property etc. In the absence of these there is no escaping from the conception of descent that the group itself has. And, in the case of the Tupi, as shown in this epigraph, it obviously tends to the paternal side. 
Anthropologists have been interested in studying the Tupi for about fifty years. Yet, since the discovery of Brazil the Tupi have always received the most attention, as these Indians were the main inhabitants of the largest part of the coast occupied by the colonisers. At that time they were known by the generic name Tupinambá, a denomination that covered the Tupi groups that occupied the Brazilian coast from Pará to Paraná, and which share a high degree of linguistic and cultural unity (Fernandes, 1963:IS). The Tupinambá were observed by a number of chroniclers (Thevet, Lery, Staden, Evreux, Anchieta, Caminha, Cardim, Nóbrega, Soares de Souza, Gandavo and Knivet among others), who, gifted with very considerable powers of observation, and very often capable of resisting the strongly established ethnocentric framework of the period, managed to bequeath us a large quantity of ethnographic data.

Alfred Metraux was the first systematically to make use of the data of the chroniclers, but his concern was restricted to the messianic migrations of the Tupi-Guarani (1927), their material culture (1928) and religion (1928). Despite the importance of these works for what they tell us of the Tupi, they failed to include important information from the chronicles with reference to kinship. Florestan Fernandes, challenged by Metraux himself, took on this task, publishing in 1949 his master's thesis A Organização Social dos Tupinambá. It must be recognised that the value of the inductive conclusions increases when we realise that the empirical examples used were the result of the observations, not always systematic, of the chroniclers of the $16^{\text {th }}$ century. In a brief study published in 1964, I showed how Fernandes succeeded in an undertaking of such magnitude and that, thanks to the perfect reconstruction of their social reality, he brought the Tupinambá Indians back to life before our eyes. His chapter on kinship is one of the finest on the subject, and it is regrettable, as Peirano (1984) notes, that it is virtually unknown to anthropology students who are more interested in the author's sociological phase.

It was precisely when I was writing the brief study mentioned above that I decided to continue the work started by Fernandes, undertaking a comparative study of the social organisation of extant Tupi,. This was made possible by the use of the data from my field research into three Tupi groups, monographs and articles by other authors, and by the opportunity to use the data on the Tupinambá analysed by Fernandes as a reference.

In my doctor's thesis - A Organização Social dos Tupi Contemporãneos - presented in 1972 at the Faculdade de Filosofia, Ciencias e Letras of the 
Universidade de São Paulo, I compared all the above-mentioned data, in particular the rules of residence and descent, the various systems of kinship relationshiops, the possibility of the existence of unilinear descent groups, in addition to seeking to present my own interpretation as regards Tupi kinship.

As we have already seen, in the works of Wagley and Galvão, as well as those of James Watson, the Tupi rule of descent was presented as being of the bilateral type. I thus sought to show my readers that this interpretation was derived from the mistake of considering that the existence of both paternal and maternal terms was an indication of bilaterality, in addition to the insistence on the part of these authors in ignoring the native conception of biological conception. This conception - and once again I refer back to this article - is eminently patrilinear. Thus, for example, a woman who is the daughter of the second marriage of the Ego mother is not considered a sister, as long as the second husband does not form part of the group of siblings of the first.

I considered the Tupi residence rules, despite the disagreement of various authors (Holmberg, 1950; Murphy, 1960; Wagley and Galvão, 1948; Watson, 1952), as patrilocal. Indeed, patrilocality was observed amongst the Mawe (Leacock, 1958), Parintintin (Betts, 1967), Tupinambá (Metraux, 1948) and in my own work amongst the Surui, Akuawa-Asurini and Urubu-Kaapor. I found the Surui dwelling in a large collective household, where one could hardly make out any special distribution of the clans. In the past each one of these groups had their own residences: in 1961 I visited the remains of three communal houses and was told that one had belonged to the Koati, the other to the Ywyra and the third to the Saopakania. At the time of this research the Akuawa-Asurini dwelt in residences of the regional type, in accordance with a neolocal rule. But before contact with whites they formed small local groups, characterised by the existence of a large communal house, in which all the male inhabitants belonged to the same patrilinear kinship group. In 1967, the Urubu-Kaapor dwelt in small houses that could suggest a neolocality, but were in fact a continuation of the patrilocal rule: the male offspring built their houses next to their fathers'. Furthermore, the myths collected indicated a marked rejection of matrilocal residence. Unilinear descent groups were only found among the Munduruku (Murphy, 1960), Parintintin (Betts, 1967) and Surui (Laraia, 1967); but an analysis of the systems of relations available for study indicated a tendency toward two section systems, where, at least theoretically, segmentation was possible. The analysis of the 
Tupi kinship system was only possible thanks to the works already cited, of Florestan Fernandes, Wagley and Galvão, Virginia Watson, Robert Murphy, Lavera Betts, in addition to those of Herbert Baldus (1970), Judith Shapiro (1968) and my own data. I thus conclude that the Tupi social structure model corresponds to a system of relations that presents a bifurcate merging in the first ascendant generation, and terms for cousins of the Iroquois type, in the Ego generation. These aspects only assume significance when they are analysed alongside the dynamic of the system, based on the rule of patrilineal descent, patrilocality and preferred marriage (ego masculine) with bilateral cross-cousins and sister's daughters. The limitations of the matrimonial rules are compensated by other mechanisms that maintain solidarity and reduce the segmentary tendencies of the system.

It is clear that my analysis does not preclude further study of the Tupi. Just as in 1977 Charles Wagley published Welcome of Tears: The Tapirape Indians of Central Brazil, the final result of research initiated in 1939; a book that was difficult to write as it ran the risk of simply confirming or repeating what had already been done by Baldus and, on a smaller scale, by Judith Shapiro. Wagley, however, achieved what he intended: unlike Baldus, he did not undertake a comparative study of the Tapirape with the other tribes of central Brazil, but opted for an analysis of greater depth, albeit applied to a smaller amount of data. His fourth chapter, "Social Organisation", stands out for its analysis of the male societies, the birds societies, promoting a clear understanding of the mechanisms of extra-parental solidarity that regulate the behaviour and cooperation between men.

His interest in the study of these associations did not prevent him, in the same chapter, from analysing kinship; this does however raise some issues. For example, on page 98, Wagley states that "between 1935 and 1939/40 neither matrilineages, nor a true, extended matrilocal family, really existed," insisting, with reference to the latter, that neither he nor Baldus observed its occurrence in actual life, although it existed "at least as an abstract model in the minds of his informers." On another occasion (Laraia 1978:208), I have suggested that both Baldus and Wagley could have committed the same type of error that led to the publication of Warde Goodenough's article "Residence Rules" (1956), that demonstrates how two anthropologists (Goodenough and J. Fischer), working with the same group at different times, arrived at two different residence rules. This error could result from deducing the rule on 
the basis of the simple observation of the composition of domestic groups rather than seeking ideal patterns of behaviour. In the case of the Tapirape, the situation is somewhat different as both the authors are in agreement as to the residence model, although worried by the fact that they were not able to observe it in actual operation.

Furthermore, the existence of matrilineal descent in a Tupi society appears to me problematic, above all when the author does not present the evidence which permitted him to arrive at this conclusion. Finally, we continue not to know with whom the young Tapirape men should marry: little progress has been made since the affirmation that in the past they married women known as sisters, albeit distant ones. It is hard to accept the existence of a Hawaiian cousin terminology, when the terms for uncles are sometimes indicated to be the bifurcate merging type and at others bifurcate collateral. It is probable that my objections are largely due to the fact that I consider the Tapirape within a Tupi model; but it should not be forgotten that they are characterised by an extraordinary mixture of cultural patterns found among the other groups of the same geographical region, a fact that must have encouraged Baldus to opt for the comparative method when he wrote his monograph.

Recently there has been an increase in field research among Tupi groups; but kinship has not been a major concern of the new researchers. In the $1^{\text {st }}$ Tupi Encounter, which took place in Sao Paulo in 1982, none of the 21 papers presented discussed the subject. The most recent work of which I am aware in which Tupi kinship is discussed is Eduardo Viveiros de Castro's excellent doctor's thesis (1984).

The Jê were first studied by Curt Nimendaju, as has already been seen, and also by Jules Henry (1941) and the Silesian priests Colbacchini and Albiseti (1942). Based on the work of Nimendaju and of Colbacchini and Albiseti, it can at least be ascertained that the Jê, as a marginal people - for the simple reason that they preferred the Central Plateau to the Amazon Forest - constitute a major contrast, with a rich ritual life of which the main characteristic is the predominance of a dual system. Since the publication of the book by the Silesians on the Bororo, anthropologists have had their attention directed at the social complexity of this group, of which one of the most striking aspects is the special projection of their system of exogamic moieties divided into matrilineal clans. The layout of the village perfectly reflects this type of social organisation. However, the spreading of this type 
of organisation to other Jê groups proved not to be operational, as these people, despite all they have in common, also reveal intriguing differences. For example, exogamic moieties were not found in other groups, but various pairs of exogamic moieties were found among the Timbira.

Melatti (1985) points out that the work of Jules Henry on the Jê group of the south differs from Nimuendaju's view of the Jê societies he studied. Whereas for the latter the behaviour of his informers is rigidly determined by their customs, the Xokleng studied by the former appear to belong "to an amorphous society, with no structure". Melatti explains this divergence as the result of Nimuendaju being concerned with ideal behaviour, whereas Henry, in line with his psychological orientation, is concerned with the individual peculiarities of actual behaviour.

Nimuendaju's ethnography, in addition to its intrinsic value, has the merit, as I have already emphasised, of provoking a great deal of interest in the social organisation of the Jê. The four Kiye, among which the Apinayé are described as capable of regulating marriage through a structure of parallel descent groups, aroused the interest of numerous anthropologists: Lowie (1940), Kroeber (1942), Murdock (1949), in addition to Lévi-Strauss who, in 1952, pulished "Les Structures Sociales dans le Brésil Central et Oriental", in which he analyses the systems of moieties found among the Xerente, Bororo and Aapinayé. He continued this work in a further article "Les Organisations Dualistes Existent'Elles?" (1956), in which the structures of moieties of the Bororo and the Timbira are compared to those of the Omakarana, Winebago and those of Indonesia.

In the first article, Lévi-Strauss refers to the system of parallel descent encountered by Nimendaju among the Apinayé, but shares the doubts of other anthropologists when he states that "the study of the social organisation of the peoples of Central and Eastern Brazil should be done all over again through field studies (...) as the real functioning of these societies is very different from the superficial appearance (...)." In the second article he specifically refers to the anomalies encountered in the moiety system of the Bororo.

In the 1960's this recommendation for new studies of the Jê was taken up by the joint research programme resulting from the cooperation between the Museu Nacional and Harvard University. Field work was undertaken by David Maybury-Lewis, the programme organiser, and Terence Turner, Joan Bamberger, Jean Carter Lave, Dolores Newton, Cecil Cook e John Christopher 
Crocker, all from Harvard, and Roberto Da Matta and Julio Cezar Melatti, both from the Museu Nacional ${ }^{5}$.

Maybury-Lewis had previous fieldwork experience with two Jê groups of Central Brazil: the Xerente and the Xavante. In 1960, his article "Parallel Descent and the Apinayé Anomaly" had solved the famous Apinayé anomaly, which had been announced by Lowie and which had mobilised the work of so many anthropologists. It thus became evident that the Kiye do not regulate marriage. The research undertaken by Da Matta confirmed that Maybury-Lewis' proposition was correct, and in addition contributed to the understanding of the kinship system of the Apinayé, in that "the list of terms published by Nimuendaju (...) was characterised by two types of paradoxical factor: (a) the majority of the terms were the same as those encountered among the other Timbira and Kayapó, but (b) the system entirely diverged from the pattern and did not easily fit into to a Crow-Omaha pattern or any other." (Da Matta 1976:17).

In his book Um Mundo Dividido, Da Matta uses the following terms for cross-cousins: $\mathrm{MDB}=$ tui-re, $\mathrm{MSB}=$ krã-tum, FZD = tamtxua, FZS = tamtxua. According to the author these terms follow an Omaha pattern, and are very close to the terminology encountered by Turner (1966) among the Kayapó. Based on his research, however, Da Matta demonstrated that alongside this type of "solution" other "solutions" of the Crow type are encountered, stating that: "the problem of cross-cousins and their classification among the Northern Jê is that of explaining why the Kayapó established these genealogical positions of an Omaha pattern and why some Eastern Timbira societies (Kraho, Gaviões and Canel) established the same positions in a Crow pattern. To clarify this important question, the Apinayé terminology, with all its discrepancies and difficulties, has a privileged position. This is because, as has been seen, the Apinayé oscillate between the Crow and the Omaha." (Da Matta, idem: 193).

The explanation encountered by Da Matta and by his colleagues on the same research programme lies in the relationship between nominators and nominated, a relationship considered by the Apinayé as equivalent to that existing between siblings of the same sex. When this relationship was present the solution was always of the Crow type, which did not occur when the nominated relationship was not referred to.

An equivalent situation occurs among the Kraho, where the Crow solution 
is altered for the Omaha when there are cases of women assigning value to their relationship with the female nominators. In other words, the sister of father begins to identify with the feminine Ego, and in consequence the latter calls the children of the father's sister children. That is why, for Melatti, "the Omaha pattern only appears in concrete cases of transmission of names by the sister of the father, with the typology of the Crow type remaining unaltered regarding the other descendants of the father's other siblings" (Melatti, 1979). For all these reasons, in addition to its geographical position, which places it in an intermediary region between the Kayapó and the Timbira, the Apinayé are considered as a perfect synthesis of the Northern Jê. In any case, it was the study of this group undertaken by Nimuendaju in the 1930's that served as the catalyst for modern anthropological studies of the Jê. These studies, which received an enormous stimulus thanks to the Museu Nacional/ Harvard Central Brazil Project, produced a far-reaching re-examination of the existing data, and resulted in some excellent doctors' theses. The crucial questions examined in these theses are contained in Dialectical Societies, a book that is dedicated to the memory of the great researcher Curt Nimuendaju. ${ }^{6}$

Studies of the Jê did not terminate with this project. A new wave of researchers from Rio de Janeiro - under the orientation of Anthony Seeger -and Sao Paulo, under the orientation of Lux Vidal or Tekla Hartmann ${ }^{7}$ continued to study the various groups of Jê. However, the only study of kinship whose results were published and of which we are aware, is Seeger's monograph on the Suyá (1981), whose seventh chapter is dedicated to the analysis of the kinship system.

For Seeger, the basis of Suyá kinship "is the identity of a group of persons who share bodily substance, a group that I have translated as "us" (kwoiyi), and their opposition to those who do not share bodily substance, translated as "others" (kukidi)" (op. cit., 121). Seeger draws attention to the characteristic that the Suyá share with other Jê groups, the fact that "there is a kinship system, but it is impinged on by a naming and a ceremonial relationship system."

The Suyá system is also classified as being of the Omaha type, but possesses marriage norms that differ from the other Jê groups. "Preferential matrilateral cross-cousin marriage, a group of siblings marrying another group of siblings, and brother-sister exchange (the exchange of men between two houses) are all considered good or ideal marriage by Suyá". Seeger also analyses the principles of nominations and shows how they correlate with the 
kinship system. This chapter is without doubt a further important contribution to the study of the Jê systems and new and important contributions are still to be expected from the anthropologists who are currently producing the results of their recent field research.

I cannot leave aside the kinship studies related to the so-called Xingu Indians, ethnographically remarkable for a sophisticated process of intertribal inter-acculturation. Although first introduced into ethnographic literature after Von den Steinen's expedition of 1884, it is with the research of Eduardo Galvão, above all his article "Cultura e Sistema de Parentesco das Tribos do Alto Xingu", published in 1953, that the subject of Xingu kinship became important in Brazilian anthropology. The model presented by Galvão is based on cousin terms of the Hawaiian type, oddly associated to the possibility of marriage between cross-cousins and to cousin terms of the bifurcate merging type in addition to rule of bilateral descent. This model, as well as becoming the subject of many discussions and controversies, provided the stimulus for numerous researches conducted among the Xingu Indians.

Indeed, the Xingu was assailed by an avalanche of anthropologists, in inverse proportion to the quality of the results they published, which, particularly as far as kinship is concerned, leave a great deal to be desired.

In 1970, Renate Brigite Viertler, based on the kinship studies undertaken among the Xingu by Cameiro, Galvão, Quain and Oberg, among others, opted for a system of the Iroquois type, casting doubt on the existence of a cousin terminology of the Hawaiian type. This is the only study undertaken by a Brazilian researcher on the subject and has not received the recognition it deserves.

It was two American researchers who, in this same decade, where to return to the preoccupation with studies of Xingu kinship: Ellen Basso and Thomas Gregor. Basso occupied a considerable part of his monograph with an analysis of the Kalapalo system. In this monograph, as in previous studies (1975, for example), the author demonstrated her preference for the approach utilized by Goodenough, Scheffler and Lounsbury, reflecting a moment when kinship studies were greatly influenced by Sociolinguistics. Gregor (1977), in his work, returned to the idea of a system of the Hawaiian type, despite stating that the system of the Mehinako is of the Dravidian type; that is, when cross-cousins "act as in-laws or potential in-laws while other kin are consanguines". He himself draws attention to the ambiguous character and 
flexibility of Mehinako kinship. At a certain point he draws even closer to Galvão when he states that "cross-cousins can be 'very much' cross-cousins or only a 'little bit' cross-cousins".

Thus, oscillating between cross-cousins at times denominated by the same terms, at others by different terms for siblings, the people of the Xingu still constitute an unsolved problem for those who study the kinship of Brazilian Indians. The large quantity of new material that now exists means that the pioneering efforts of Viertler can now be repeated with a greater chance of success.

The study of kinship among the Tupi, the Jê and the people of Xingu accounts for a considerable portion of the work undertaken by modern Brazilian anthropologists; but there are also independent researchers who have studied kinship in other societies. Even at the risk of committing the grave error of omission, I would like to mention a few:

Roberto Cardoso de Oliveira, whom I have already mentioned in the context of his study of the Terena matrimonial system, also studied Tukuna society, that was studied previously by Curt Nimuendaju (1952). According to Cardoso de Oliveira (1961) this society is broken down into clans and patrilinear moieties. Whereas the former, generically referred to as "kie" possess a specific name, the moieties are anonymous and classify the "kie" in two distinct groups: one associated with the names of plants (even though related to certain insects and animals) and the other with names of fowl. In this study the author attempted, in my opinion, to substitute the concept of lineage for that of UGDD (unilinear group of demonstrated descent). The explanation that he gave for this procedure was that the UGDD, although they have characteristics of lineages, cannot be confused with them due to their peculiarities of emerging social units.

The subject of the anonymous moieties was taken up again by Cardoso de Oliveira in an interesting article published in 1964 in which the plant/fowl duality is examined in the light of a modern conception of totemism.

In 1964, in O Índio e o Mundo dos Brancos, a book dedicated to the interethnic relationships between the Tukuna and whites, he undertakes a componential analysis of Tukuna kinship in the only published attempt by a Brazilian author to investigate the kinship terminology from a semantic point of view, reflecting the influence, albeit temporary, of authors like Goodenough, Lounsbury, Wallace and Atkin. 
Alcida Rita Tamos (1972) studied the social system of the Sanumá, a Yanoama subgroup, in the Federal Territory of Roraima. Her doctor's thesis, presented at the University of Wisconsin, is a very complete study of the Sanumá kinship system and the agnatic principles that govern it. Utilizing the sib concept, almost unknown to contemporary Brazilian anthropologists who prefer the clan concept, she studied in depth the role of the lineages in a segmented non-hierarchical system. This initial analysis was the departure point for her later work on Sanumá naming, which differentiates between the public and private name (1976), and requires rules for labels that encourage the use of the practice of teknominy in a far broader form than the classical teknominy that uses only two kinship terms. In the case of the Sanumá, the number of terms involved is eight, allowing for, as the authors states (1977), operation in a far larger field of action and appropriate for a larger number of combinations and permutations.

It was not my intention to analyse the entire scientific output on kinship among the Brazilian Indians, but rather to give an idea of the nature of this production. I believe that the examples given are more than adequate; however, the interested reader has at his or her disposal the work of Diniz (1972) on the Makuxi, that of Rivière (1969) on the Tirio, that of Kracke on the Kagwahib (1976 and 1984), as well as innumerable other articles and writings. I have intentionally left aside all the modern work that is being undertaken concerning the nature of family organisation in our own society. These are stimulating studies that deserve to be the subject of a future article. In this one my intention has been to demonstrate how Brazilian anthropology has been concerned with the analysis of indigenous kinship systems. In addition, albeit superficially, I have tried to demonstrate the main methodological orientation. And these, in my opinion, show a high degree of intercommunication with the anthropology of developed countries.

\section{Bibliografia}

ARNAUD, Expedito. 1963. "A Terminologia de Parentesco dos Índios Asurini".

Revista do Museu Paulista, NS, XIV, pp. 105-119.

BALDUS, Herbert. 1952. "Terminologia de Parentesco Kaingang”. Sociologia, XIV, n. 1, pp. 76-79.

BALDUS, Herbert. 1970. Tapirape, Tribo Tupi no Brasil Central. São Paulo, Cia. 
Editora Nacional/Editora da Universidade de São Paulo.

BAMBERGER, Joan. 1967. Environment and Cultural Classification: A Study of

Northern Kayapo. Doctoral dissertation, Cambridge, Harvard University. BASSO, Ellen. 1973. The Kalapalo Indians of Central Brazil. Nova York, Holt,

Rinehart and Winston, Inc.. 1975. "Kalapalo Affinity: its Cultural and Social Contexts". American Anthropologist, v. 2, n. 2, pp. 207-228.

BETTS, Lavera. 1967. “Anthropological Check List Parintintin”. Summer Institute of Linguistic, mimeo.

CARDOSO DE OLIVEIRA, Roberto. 1959. "Matrimônio e Solidariedade Tribal Terena". Revista de Antropologia, VII, pp. 31-48.. 1961. "Aliança Interclânica na Sociedade Tukuna”. Revista de Antropologia, IX, n. 1 e 2, pp. 15-32.

CARDOSO DE OLIVEIRA, Roberto. 1964. “Totemismo Tukuna?”.

Völkerkundliche Abhandlungen-Band 1, Niedersäch-sisches

Landesmuseum Hannover, Hannover, pp. 233.248.

CARDOSO DE OLIVEIRA, Roberto. 1964. O Índio e o Mundo dos Brancos. São Paulo, Difusao Européia do Livro.

COLBACCHInI, Antonio e Albiseti, Cesar. 1942. Os Bororos Orientais

Oraramogodogue do Planalto Oriental de Mato Grosso. São Paulo, Brasiliana, Série Grande Formato IV.

DA MATTA, Roberto. 1970. Apinayé Social Structure. Doctoral Dissertation, Cambridge, Harvard University.

DA MATTA, Roberto. 1976. Um Mundo Dividido, a Estrutura Social dos Índios Apinayé. Petrópolis, Editora Vozes Ltda.

DINIZ, Edison Soares. 1972. “Os Índios Makuxi do Roraima”. Faculdade de Filosofia, Ciências e Letras de marília, Coleção Tese n. 9.

DREYFUS, Simone. 1963. “Les Kayapó du Nord, État de Pará-Bresil”. École Pratique des Hautes Études, Sorbonne, Études XXIV.

DRUMOND, Carlos. 1943. "Designativos de Parentesco no Tupi-Guarani”.

Sociologia, v. V, n. 4, pp. 328-354.

FERNANDES, Florestan. 1963. “A Organização Social dos Tupinambá”. 2a edição, São Paulo, Difusão Européia do Livro.

FERNANDES, Florestan. 1970. “A Função Social da Guerra na Sociedade

Tupinambá”. São Paulo, Livraria Pioneira Editora/Editora da Universidade de São Paulo.

GAlVAO, Eduardo E. 1953. "Culturas e Sistemas de Parentesco das Tribos do Alto Rio Xingu”. Boletim do Museu Nacional, NS, n. 14. 
GARCIA, Rodolfo. 1942. "Nomes de Parentesco em Língua Tupi”. Anais da Biblioteca Nacional do Rio de Janeiro, LXIV, pp. 177-189.

GOODENOUGH, Ward. 1956. "Residences Rules”. Southwestern Journal of Anthropology, v. 12, pp. 22--37

GREGOR, Thomas. 1977. Mehinaku - The Drama of Daily Life in a Brazilian Indian Village. Chicago, The University of Chicago Press.

HENRY, Jules. 1941. Jungle People. A Kaingang Tribe of the Highlands of Brazil. New York.

HOCART, A. M. 1937. “Kinship Systems”. Anthropos, v. 32, pp.345-351.

HOLMBERG, Allan R. 1950. "Nomads of the Long Bow", Publication n. 10, Smithsonian Institution, Washington.

KRACKE, Waud. 1976. "Uxorilocality in Patriliny: Kagwahib Filial Separation”. Ethos, v. 4, n. 3, pp. 295-310.

KRACKE, Waud. 1984. "Kagwaib Moieties: Form Without Function?”. In K. Kensiger (ed.), Marriage Practices in Lowland South America. University of Illinois Press.

KROEBER, A. L. 1942. “The Societies of Primitive Man”. Biological Symposia, v. 8, Lancaster.

LARAIA, Roque de Barros. 1964. "Resenha de Organização Social dos Tupinambá”. In America Latina, Ano 7, n. 3.

LARAIA, Roque de Barros. 1972. "A Organização Social dos Tupi Contemporâneos”. Dissertação de doutorado, Universidade de São Paulo.

LARAIA, Roque de Barros. 1978. "De Como uma Tribo Cativou um Antropólogo". Anuário Antropológico/77, pp. 203·213.

LARAIA, Roque de Barros e DA MATTA, Roberto. 1967. Índios e Castanheiros. São Paulo, Difusão Européia do Livro.

LAVE, Jean Carter. 1967. Social Taxonomy among the Krikrati (JE) of Central Brazil. Doctoral Dissertation, Cambridge, Harvard University.

LEACOCK, Seth. 1958. Economic and Social Factors in Maue Persistence. Doctoral Dissertation, Berkeley, University of California.

LÉVI-STRAUSS, Claude. 1952. "Les Structures Sociales dans le Brasil Central et Oriental". Proceedings of the 29th Congress of Americanists. Chicago, University of Chicago Press.

LÉVI-STRAUSS, Claude. 1956. “Les Organizations Dualistes Existent'Elles?”. Bijdragen tot de Taal-, Landen Volkenkunde, Deel 112, 2e Aflevering. 's-Gravenhage, pp. 99-128. 
LÉVI-STRAUSS, Claude. 1958. Anthropologie Structurale. Paris, Librairie Plon. LOWIE, Robert. 1941. "A Note on the Northern Ge of Brazil”. American Anthropologist, ns. v. 43.

MACDONALD, Frederick. 1965. "Some Considerations about Tupi-Guarani Kinship Structures” Boletim do Museu Paraense Emilio Goeldi, Antropologia, n. 26.

MAYBURY-LEWIS, David. 196o. "Parallel Descent and Apinayé Anomaly" SouthWestern Journal of Anthropology, v. 16, pp. 191-216.. 1967. Akwê-Shavante Society. Oxford, Clarendon Press.

MAYBURY-LEWIS, David. 1979. Dialetical Societies. Cambridge, Harvard University Press.

MELATTI, Julio Cezar. 1968. "Nominadores e Genitores: um Aspecto do Dualismo Krahó". Verhandlungen des XXXVIII Internationalen Americanisten Kongress, Stuttgart-München 12, bis 18, August, 1968, Kommissionswelag Klaus Renner, 1971, Band III, pp. 347-353.

MelatTi, Julio Cezar. 1973. "O Sistema de Parentesco dos Índios Krahó”.

Fundação Universidade de Brasília, Departamento de Ciências Sociais, Série Antropologia 3.

MELATTI, Julio Cezar. 1979. “The Relationship System of Krahó”. In MayburyLewis (ed.), Dialetical Societies. Cambridge, Harvard University Press. MElATti, Julio Cezar. 1985. “Curt Nimuendaju e os Jê”. Fundação Universidade de Brasília, Departamento de Ciências Sociais, Série Antropologia 49.

metrauX, Alfred. 1927. "Migrations Historiques des Tupi-Guarani”. Journal de la Societé des Americanistes, NS, v. XIX, pp. 1-45.. 1928. La Civilization Materielle des Tribus Tupi-Guarani. Paris. Librairie Orientaliste Paul Geuthner.. 1928. La Religion des Tupinambá et ses Rapports avec celle des Autres Tribus TupiGuarani. Paris, Librairie Ernest Leron.

MURDOCK, George. 1949. Social Structure. New York, The MacMillan Co. MURPHY, Robert. 1960. Heandhunter's Heritage. Berkeley and Los Angeles. University of California Press.

NEEDHAM, Rodney. 1962. "Notes on Comparative Method and Prescriptive Alliance”. Bijdragen tot de Tall-Land-en Volkenkunde 1181, 1 Aflevering: 160-182.

NIMUENDAJU, Kurt. 1934. The Apinayé. Washington, Catholic University of American Press.

NIMUENDAJU, Kurt. 1942. The Serente. Los Angeles, Frederick Weeb Hodge Aniversary Publication. 
NimUENDAJU, Kurt. 1946. The Eastern Timbira. Berkeley and Los Angeles, University of California Press.

NIMUENDAJU, Kurt. 1952. The Tukuna. Edited by Robert Lowie, University of California. Publications in American Archaelogy and Ethnology. Berkeley and Los Angeles.

PEIRANO, Mariza. 1984. "A Antropologia Esquecida de Florestan Fernandes". Anuário Antropológico/82, pp. 15-52.

PHILIPSON, Jurn. 1946. "Notas sobre a Interpretação Sociológica de Alguns Designativos de Parentesco no Tupi-Guarani”. Boletim LVI, Faculdade de Filosofia, Letras e Ciências da Universidade de São Paulo.

RAMOS, Alcida. 1972. The Social System of the Sanumá of Northern Brazil. Doctoral Dissertation, University of Wisconsin, Madison.

RAMos, Alcida. 1976. "O Público e o Privado: Nomes Pessoais entre os Sanumá”. Anuário Antropológico/76, pp. 13-38.

RAMOS, Alcida. 1977. "Tecnominia e Conceitualização Social entre os Índios Sanumá”. Anuário Antropológico/77, pp. 148-167.. 1978. "Munduruku: Social change or False Problem”, in American Ethnologist, vol. 5, n. 4, pp. 675-689. RIBEIRO, Darcy. 1948. “Sistema Familiar dos Kadiwéu”. Revista do Museu Paulista, NS. v. II. 1948.

RIVIÈ RE, Peter. 1969. Marriage among the Trio. Oxford. Claredon Press. SCHADEN, Egon. 1954. Aspectos Fundamentais da Cultura Guarani. Faculdade de Filosofia, Letras e Ciências, da Universidade de São Paulo. Boletim. Republicado pela Difusão Européia do Livro, 1962.

SEEGER, Anthony. 1974. Nature and Culture and Their Transformations in the Cosmology and Social Organization of Suyá, a Ge-Speaking Tribe of Central Brazil. Doctoral Dissertation, University of Chicago.

SEEGER, Anthony. 1981. Nature and Society in Central Brazil. Cambridge, Harvard University Press.

SHAPIRO, Judith. 1968. “Tapirapé Kinship”. Boletim do Museu Paraense Emilio Goeldi. Anlropologia, n. 37.

TURNER, Terence. 1966. Social Structure and Political Organization among the Northern Cayapó. Doctoral Dissertation, Cambridge, Harvard University. VIERTLER, Renate B.. 1970. Os Kamayura e o Alto Xingu. Instituto de Estudos Brasileiros, Universidade de São Paulo.

VIVEIros DE CASTRO, Eduardo. 1984. Araweté: Uma Visão da Cosmologia e da Pessoa Tupi-Guarani. Tese de Doutorado, Museu Nacional. 
WAGLEY, Charles. 1977. Welcome of Tears: The Tapirape Indians of Central Brazil. New York. Oxford University Press.

WAGLEY, Charles e GALVÃo, Eduardo. 1946. "O Parentesco Tupi-Guarani”. Boletim do Museu Nacional, NS, Antropologia, n. 6.

WAGLEY, Charles e GALVÃO, Eduardo. 1948. "The Tapirapé. Handbook of South American Indians. Smithsonian Institution, Bureau of American Ethnology, Boletim 143, v. 3, pp. 167-178.

WAGLEY, Charles e GALVÃO, Eduardo. 1948. “The Tenetehara”. Handbook of South American Indians, idem.

WAGLEY, Charles e GALVÃO, Eduardo. 1949. The Tenetehara Indians of Brazil:

A Culture in Transition. New York, Columbia University Press.

WATSON, James. 1952. Cayuá Culture Change: a Study in Acculturation and

Methodology. Publicação da American Anthropological Association,

Memoir n. 197.

WATSON, Virginia. 1944. "Notas sobre o Sistema de Parentesco dos Índios Cayuá".

Sociologia, v. VI, n. 4, pp. 31-48.

\section{(Endnotes)}

1 For the purposes of this study I will consider as a part of Brazilian anthropology the work of foreign researchers whose field research was undertaken in Brazil. Many of them maintained their ties with the development of the discipline in this country, visiting frequently, participating in meetings, incorporating Brazilian researchers into their programmes. This is not, however, the case of Nimuendjau, who lived most of his life in Brazil, between 1903 and 1946, when he died among the Tukuna Indians.

2 Wagley and Galvão's article was criticised by Philispon (1946) who alleged that "Tupi Guarani kinship does not exist, but different systems in different groups”. Philipson's linguistic perspective, which was the cause of his disagreement with the two authors, is the reason why his work, along with that of Garcia and Drummond, is only touched upon in this article.

3 As will later be seen, Alfred Metraux was the first anthropologist to use the data left by the chroniclers. But he showed little interest in the data referring to kinship and social organisation as a whole.

4 It should be mentioned that the quotation from Turner is from a 
mimeographed study, whereas that of Maybury-Lewis was taken from a publication of the Oxford University Press, from which it can be supposed that Turner's was produced earlier.

5 The French contribution to the study of the Jê should not be forgotten, through the work of Simone Dreyfus (1963), in which, in addition to analysing the kinship system of the group, she compares it to the Xerente and Timbira systems.

6 Here I am only referring to those studies published on the Jê that emphasise social organisation. The numbers of those who have studied the Jê societies is larger than the members of the programme referred to, but centre on other aspects of the culture. However, William Crocker should be mentioned, who concerned himself with the factionalism of the Canela and is, without doubt, the anthropologist who has spent most time studying the Timbira. 7 Continuing the work of Hartmann, Renate Brigite Viertler has undertaken and coordinated numerous research projects among the Bororo. 